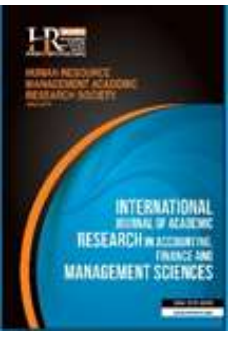

International Journal of Academic Research in Accounting, Finance and Management Sciences

Vol. 10, No. 1, January 2020, pp. 345-350

E-ISSN: 2225-8329, P-ISSN: 2308-0337

(c) 2020 HRMARS

www.hrmars.com

To cite this article: Permata, S. P. Handoyo, R. D., Ridzuan, A. R., Md Razak, M. I. (2020). Non-Tariff Measures Impact on Indonesian Fishery Export, International Journal of Academic Research in Accounting, Finance and Management Sciences 10 (1): 345-350

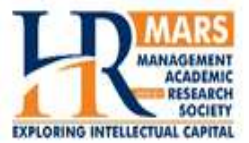

\title{
Non-Tariff Measures Impact on Indonesian Fishery Export
}

\author{
Sonia Puspa Permata ${ }^{1}$, Rossanto Dwi Handoyo ${ }^{2}$, \\ Abdul Rahim Ridzuan ${ }^{3}$, Mohamad Idham Md Razak ${ }^{4}$ \\ ${ }^{1,2}$ Faculty of Economics and Business, Universitas Airlangga \\ ${ }^{1}$ E-mail: Sonia.puspa.permata-2014@feb.unair.ac.id, ${ }^{2} E$-mail: Rossanto_dh@feb.unair.ac.id \\ ${ }^{3,4}$ Faculty of Business and Management, Universiti Teknologi MARA, Melaka Campus, Malaysia \\ 33-mail:Rahim670@staf.uitm.edu.my, ${ }^{4}$ E-mail: iedham@warga.uitm.edu.my
}

\begin{abstract}
This study aims to analyze the impact of Non-tariff measures using a sanitary and phytosanitary policy (SPS) and technical trade barriers (TBTS) on fishery exports of Indonesia and its trading partner countries, China, South Korea, Vietnam, Canada, Russia and the European Union in the period of 2007 to 2016. SPS and TBT are measured using an inventory approach in the form of coverage ratio. Besides, this study uses a gravity model and panel data regression method. The results of this study indicate that the variables GDP of exporting country and GDP of importing country have a positive and significant effect on Indonesian fishery exports. Distance and SPS have a negative and significant effect on Indonesian fishery exports, while TBT does not affect Indonesian fishery exports.

Key words Export, SPS and TBT, Fishery Export, Coverage Ratio

Received: 28 Apr $2020 \quad$ (C) The Authors 2020

Revised: 08 May 2020 Published by Human Resource Management Academic Research Society (www.hrmars.com)

Accepted: 12 May 2020 This article is published under the Creative Commons Attribution (CC BY 4.0) license. Anyone may reproduce, distribute, translate and create derivative works of this article (for both commercial and

Published Online: 18 May 2020 non-commercial purposes), subject to full attribution to the original publication and authors. The full terms of this license may be seen at: http://creativecommons.org/licences/by/4.0/legalcode
\end{abstract}

\section{Introduction}

The high production of world fishery products boosted global fisheries trade to 130 billion USD by 2015 (FAO, 2015). The globalization of food trade and technology advancement in the process of production, processing and distribution can cause consumers to demand quality and high-quality assurance on products consumed. The matter is addressed as a problem and the primary focus for governance in many countries, not least Indonesia. Indonesia still faces high barriers non-tariff, particularly in the fishery sector, in international trade. The high non-tariff barriers in the fisheries sector are preceded by environmental issues such as eco-labelling and protection of certain animal species (Ministry of Trade of Republic of Indonesia, 2014). The trade of Indonesia's fishery sector is not only influenced by supply and demand factors but also influenced by international trade policy factors that ensure the safety standards of a product. In maintaining the quality of fishery product safety, Indonesia needs to improve and harmonize the system of quality assurance and security of fishery products with export destination countries or countries. Notably, among the six cooperating in the field of fisheries, i.e. the European Union, Canada, South Korea, China, Russia, and Vietnam. Even though MRA still has a case of rejection of export of Indonesian fishery products in its trading partner country, which can be seen in Figure 1 (BKIPM, 2016).

The reasons for the refusal case of Indonesian fishery exports as a whole are related to the sanitary and phytosanitary policy (SPS) and technical trade barriers (TBTs) both of which have been negotiated in 
the Uruguay GATT rounds of Uruguay in 1986. The main objective of the policy is to protect people, animals and plants on a country of disease and ensures national prosperity by improving market failures (Aloka et al., 2009).

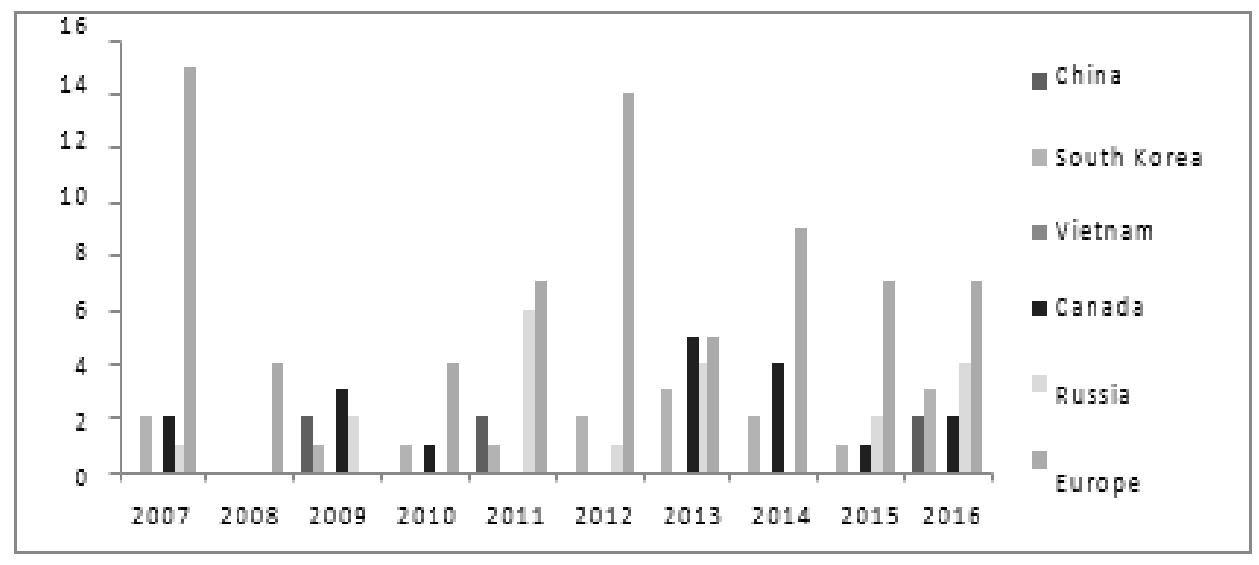

Figure 1. Number of Export Rejection Cases of Indonesian Fisheries to Trade Partner Countries from 2007 until 2016

Source: BKIPM Ministry of Marine Affairs and Fisheries 2016

The use of SPS policy is implemented to regulate agriculture and animal products. The SPS policy is an essential control to ensure the health, the well-being of consumers, and protection of the environment. As a result of such use, more than 60 per cent of food-related products were found to be affected by at least one of the forms of SPS policy (UNCTAD, 2013). Research conducted by Thu Thuong (2017) and Hwang and Lim (2017), suggests that SPS policies can act to preclude or precisely reduce the amount of trade in agricultural and food products.

TBT policy applies to import restrictions based on specific product characteristics (UNCTAD, 2003). Due to the increasing importance of implementation and the complexity of TBT, researchers are beginning to pay attention to understanding the impact of TBT on trafficking. Most studies have asked whether TBT can promote or limit trade. The results of the study found that TBT, in general, limited the flow of international trade (Bao \& Qiu, 2012).

Based on the above background description, this research will analyze the influence of NTM in the form of SPS and TBT policy on Indonesian fishery exports with trading partner countries such as EU, Canada, South Korea, China, Russia and Vietnam in 2007 to 2016. Trade partner countries are countries that have signed a mutual recognition agreement (MRA) in the field of fisheries with Indonesia. SPS and TBT policies were measured using an inventory approach which is coverage ratio. Independent variables used in this study include exporter country GDP and importer country GDP, geographical distance between countries, SPS policy, and TBT policy.

\section{Literature review}

NTM's measures and in particular, technical measures have been a hallmark of international trade in goods regulation. Most technical regulations are grouped into two main categories, namely sanitation or phytosanitary (SPS) and technical barriers to trade (TBT) (Fugazza, 2013).

Some studies have found that NTM has a negative impact on trade (Diesdier et al., 2008; Wei et al., 2012; Shepotylo 2016). Other research shows that the SPS policy by China negatively impacts exports from Japan and the United States (Wood et al., 2017). The SPS policy applied by Vietnamese trading partner countries can reduce rice exports from Vietnam (Thu Thuong, 2017). In other studies, it is mentioned that the impact of TBT policies imposed by developed countries is stronger than the developing countries (Bao \& Qui, 2012).

SPS and TBT policies have important implications for international trade. The policy sets out three basic principles (UNCTAD, 2013): (1). Regarding the process of elaboration and implementation of the 
policy, in addition to transparency requirements, policies must be designed on de jure basis and applied de facto in a way that is not discriminatory. This means that countries implementing SPS and TBT policies must be fair, in the sense that they do not benefit certain producers or products; (2) Proportionality to the objectives to be achieved. In this case, related efficiency criteria in choosing and implementing policies; (3) based on need. The policies that are chosen and applied are indispensable to the country in conducting international trade.

SPS and TBT policies require better production processes, investments in new technologies, efficient trade infrastructure, and the use of more expensive delivery methods that are often applied to developing countries. Also, SPS and TBT policies are often governed by a series of conformity assessments that cost, complexity, and duration depend on factors of production.

Therefore, the implementation of complex and sometimes inconsistent regulatory and conformity regulations can lead to SPS and TBT policies being a barrier to developing countries because it creates barriers to unfair market access to developed markets (UNCTAD, 2013).

Analysis of SPS and TBT implementation uses inventory approach. This approach is used to carry out an inventory of non-tariff policies, especially SPS and TBT conducted by each country. This approach consists of two types: the frequency index and the coverage ratio in the period adjusted for the availability of the data. Coverage ratios represent a percentage of the trade of a product that NTM imposed on the importing country and provided a measure of the importance of imported NTM as a whole (UNCTAD, 2013). Besides, coverage ratios have been widely applied to some previous studies (Diesdier et al., 2008; Wood et al., 2017).

\section{Methodology of research}

The model of gravity is one model to measure the impact of NTM on trade (Ferrantino, 2006). In the context of trade, this model states the intensity of inter-state trade that is positively related to the exporter and importer's Gross Domestic Product (GDP), and negatively related to the distance between countries (Krugman \& Obstfeld, 2009).

Several previous studies have shown results that GDP exporters and GDP importers have a positive relationship to trade (Diesdier et al., 2008; Bao \& Qiu, 2012; Nugroho, 2014; Shepotylo, 2016; Hwang, 2017). The distance variables used as transportation cost proxies indicate that there is a negative relationship between distance and trade (Diesdier et al., 2008; Bao \& Qiu, 2012; Wei et al., 2012; Nugroho, 2014; Shepotylo, 2016; Thu Thuong, 2017; Hwang, 2017; Wood et al., 2017)

$$
\ln X_{i j s t}=\beta_{o}+\beta_{1} \ln G D P_{i t}+\beta_{2} \ln G D P_{j t}+\beta_{3} \ln D i s t_{i j}+\beta_{4} S P S_{j s t}+\beta_{5} T B T_{j s t}+\varepsilon_{i j}
$$

$\mathrm{X}_{\mathrm{ijst}}$ is the export of Indonesian fisheries to trading partner countries in the year t; GDP it is Gross Domestic Product of exporter countries in the year $\mathrm{t}$; $\mathrm{GDP}_{\mathrm{jt}}$ is Gross Domestic Product of importer countries in the year $\mathrm{t}$; $\mathrm{D}$ is the geographical distance between the exporter and the importer country in the year $\mathrm{t}$; $\mathrm{P}$ is Sanitary and Phytosanitary (SPS) of importer country to Indonesian fishery in the year t; B is a Technical Barrier Trade (TBT) of importer country to Indonesian fishery in the year $t$.

The panel data regression method is used to see the effect of exporter GDP variables (GDP of Indonesia), GDP of importer countries (GDP of European Union, China, South Korea, Vietnam, Canada and Russia), geographical distance, sanitation and phytosanitary (SPS) and technical barriers trade (TBT) in the period 2007-2016.

\section{Results and discussions}

This study uses panel data, a combination of cross-section and time-series data. Panel data can be estimated with three methods, Pooled Least Square (PLS), Fixed Effect Model (FEM), and Random Effect Model (REM). In determining which model to be used appropriately, it can be done with three tests, i.e. Fstatistic test, Hausman test and Lagrange Multiplier test.

After regression using Pooled Least Square (PLS), Fixed Effect Model (FEM), and Random Effect Model (REM), the result of FEM regression in STATA 13 variable distance cannot be estimated (omitted). Based on these results, it is not possible to estimate using FEM because the variability in the variable 
distance between countries is very low, causing the parameter cannot be estimated. The Lagrange Multiplier test is used to select the best model between Pooled Least Square or Random Effect Model. In the results obtained from the Lagrange Multiplier test, the chi-square probability value shows less than the degree of significance of ten per cent. The best estimation model for this research is the Random Effect Model. Based on the Lagrange Multiplier test, the best model is the Random Effect model.

The REM estimation results in Table 1 show that the exporter GDP variable (GDPi) has a positive and significant relationship. It shows when a one per cent increase in GDPi will boost Indonesia's fishery exports by 0.624 per cent. The importer GDP variable (GDPj) also has a positive and significant relationship, meaning that when a one per cent increase in GDPj will increase Indonesian fishery exports by 1.36 per cent. The distance variables (DIST) in REM estimation results show a negative and significant relationship to Indonesian fishery exports. This means that when a one per cent increases in distance will decrease Indonesia's fishery exports by 2.91 per cent.

The NTM SPS variable has a negative and significant relationship to Indonesian fishery exports. This means that when a one per cent increases in SPS will reduce the export of fisheries Indonesia by 0.145 per cent. Another NTM variable is TBT which has a positive and insignificant relationship. The probability value is greater than the level of significance $(\alpha)$ of ten per cent stated the TBT variable is not significant in affecting Indonesian fishery exports.

Table 1. Random Effect Model Estimation Result

\begin{tabular}{cc}
\hline & Coefficient \\
\hline Cons & $29.19295^{* * *}$ \\
InGDPi & $0.6243749 * * *$ \\
InGDPj & $1.361979 * * *$ \\
LnDist & $-2.91618^{* * *}$ \\
SPS & $-0.1454718^{*}$ \\
TBT & 0.06227192 \\
\hline
\end{tabular}

Note: $*, * * * *$ siginificant at $10 \%, 5 \%$ and $1 \%$.

The GDP of exporters in this study is that Indonesia's GDP statistically has a positive and significant effect on Indonesian fishery exports. Based on the theory of gravity model, exporter GDP has a proportional relationship to international trade. High exporter GDP shows high production levels both in the production of goods and services. The high level of production of a country will cause exports to experience enhancement. This estimation is consistent with previous research which states that exporter's GDP has a positive effect on exports (Diesdier et al., 2008; Bao \& Qiu, 2012; Shepotylo, 2016; Hwang, 2017).

The GDP of importers in this study statistically has a positive and significant effect on Indonesian fishery exports. According to the theory of the gravity model, high GDP importers indicate the level of consumption in the country is high. High country consumption levels indicate high levels of demand in the country. The importer GDP variables that show a positive relationship under previous research which states when the GDP of importers increases, exports also increase (Diesdier et al., 2008; Bao \& Qiu, 2012; Wei et al., 2012; Nugroho, 2014; Shepotylo, 2016; Hwang, 2017).

Geographical distance is one of the critical conditions in the gravity model. Based on the theory of gravity model, distance has a negative effect on international trade relations. The estimation results obtained in this study shows that Indonesia's geographical distance with its trading partner countries has a negative and significant impact on Indonesian fishery exports. The distance variables indicate that the further the distance between the destination country and the exporting country, the greater the cost of transport for the trade to be carried out by both countries (Diesdier et al., 2008; Nugroho, 2014; Shepotylo, 2016; Thu Thuong, 2017; Hwang, 2017; Wood et al., 2017).

SPS policy shows the estimation results is following the research hypothesis that has a negative and significant impact on the fishery exports of Indonesia. The enforcement of NTM, especially SPS, is done as trade protection of a country. SPS policies often increase the fixed and marginal costs of trade or production costs of a country wishing to export to a country that implements SPS. Research conducted by Wood et al. (2017), states that this SPS policy has a distorting effect because it targets the product regardless of its origin. The effects of distortion and trade restrictions are one of the most important 
reasons of why SPS policies are increasingly being concerned in the matter of their impact on international trade. Therefore, SPS policy has an impact on trade restrictions, particularly on agricultural and food products. Developed countries apply SPS policies to products primarily from developing countries. Most developing countries cannot meet strict regulations because of their low awareness, technology, and capital (UNCTAD, 2013). The estimation results are following previous research which states that the SPS policy can reduce the export of a country (Wei et al., 2012, Thu Thuong, 2017).

In this study, TBT variable estimation results showed the positive and insignificant value in influencing Indonesia fishery exports. The results of this estimate do not match the existing theories in previous studies that the implementation of TBT policy of a country will prevent a country that will export to the country (Bao and Qiu, 2012).

\section{Conclusions and policy recommendations}

This study analyzes the impact of NTM enforcement in the form of SPS and TBT policies of trading partner countries on Indonesian fishery exports from 2007 to 2016. Indonesia's trading partner countries in the field of fisheries are China, South Korea, Vietnam, Canada, Russia and the European Union. Based on the results of the study, GDP exporters (GDP Indonesia) and GDP importers (GDP of China, South Korea, Vietnam, Canada, Russia and the European Union) have a positive and significant relationship to Indonesian fishery exports.

The distance between Indonesia and China, South Korea, Vietnam, Canada, Russia and the European Union has a significant and negative effect on Indonesian fishery exports. SPS policies enacted by China, South Korea, Vietnam, Canada, Russia and the European Union have a significant and negative effect on Indonesia's fishery exports. On the other hand, TBT policies imposed by China, South Korea, Vietnam, Canada, Russia and the EU have no significant effect on Indonesian fishery exports.

Based on the results of the above study, SPS policies applied by trading partner countries have a negative and significant impact on Indonesian fishery exports. Therefore, the Indonesian government, especially BKIPM (Fish Quarantine Agency, Quality Control and Fishery Products Security) is expected to improve the implementation of quality assurance system, health certification, and handling cases of detention and export refusal.

For further research, the research can be developed with the specific commodity of other fishery export of Indonesia, for instance, the commodity of the mainstay of fishery and agriculture sector. NTM measurements in this study using the coverage ratio approach, further research can be done with other available approaches such as price comparison, quantity impact, and computable general equilibrium model.

\section{References}

1. Aloka, B., Wijerathne, B., and Weerahewa, J. (2009). Impacts of Non-Tariff Measures (NTMs) on Agricultural Exports: A Gravity Modeling Approach. Asia - Pacific Trade Economists Conference. Srilanka: ESCAP.

2. Fish Quarantine Agency, Quality Control and Fishery Products Safety of the Ministry of Marine Affairs and Fisheries. 2016. Performance Report of 2016. (www.bkipm.kkp.go.id) accessed on 30 November 2017.

3. Bao, X., and Qiu, L. D. (2012). How Do Technical Barriers to Trade Influence Trade? Journal of International Economics 20(4), 691-706.

4. CEPII. (2017). Geographical distance data. (www.cepii.fr) accessed on 14 Oktober 2017.

5. Diesdier, A. C., Fontagne, L., and Mimouni, M. (2008). The Impact of Regulation on Agricultural Trade: Evidence from SPS and TBT Agreements. American Agricultural Economics Association, 90(2), 336350.

6. Ferrantino, M. (2006). Quantifying the Trade and Economic Effects of Non-Tariff Measures, OECD Trade Policy Papers, No. 28, OECD Publishing, Paris.

7. Food and Agriculture Organization. (2015). Production and Trade. (www.fao.org) accessed on 4 October 2017. 
8. Fugazza, M. (2013). The Economics behind Non-Tariff Measures: Theoretical Insights and Empirical Evidence. United Nation.

9. Henson, S., and Loader, R. (2001). Barriers to Agricultural Exports from Developing Countries: The Role of Sanitary and Phytosanitary Requirements. World Development, 29(1), 85-102.

10. Hwang, C. W., and Lim, S. S. (2017). Effect of Non-Tariff Measures on International Tea Trade. Journal of Korea Trade.

11. Ministry of Trade. (2014). Export News. (www.kemendag.go.id) accessed on 1 December 2017.

12. Krugman, P. R., and Obstfeld, M. (2009). International Economics: Theory and Policy. 8th edition. Boston: Addison-Wesley.

13. Nugroho, A. (2014). The Impact of Food Safety Standard on Indonesia's Coffee Exports. Procedia Environmental Sciences, 20, 425-433.

14. Shepotylo, O. (2016). Effect of Non-Tariff Measures on Extensive and Intensive Margins of Exports in Seafood Trade, Marine Policy, 68, 47-54.

15. Thu Thuong, N. T. (2017). The Effect of Sanitary and Phytosanitary Measures on Vietnam's Rice Exports. Economic, 1-15.

16. UNCOMTRADE (2016). Indonesia Fishery Export-Import Data. (https://comtrade.un.org/) Accessed on 3 October 2017.

17. UNCTAD (2003). Dispute Settlement World Trade Organization 3.10 - Technical Barriers to Trade. New York and Geneva.

18. UNCTAD. (2013). Non -Tariff Measures to Trade: Economic and Policy Issues for Developing Countries, Developing Countries in International Trade Studies. New York and Geneva.

19. Wei, G., Huang, J., and Yang, J. (2012). The Impact of Food Safety Standard on China's Tea Exports. China Economic Review, 23, 253-264.

20. Wood, J., Wu, J., Li, Y., and Jang, H. (2017). The Economic Impact of SPS Measures on Agricultural Exports to China: An Empirical Analysis Using the PPML Method. Social Science, 6(51).

21. World Bank. (2016). Data of Gross Domestic Product of 2007-2016. (www.worldbank.org) accessed on 25 October 2017

22. World Trade Organization Integrated Trade Intelligence Portal. (2016). Data Non-Tariff Measures of 2007-2016. (https://i-tip.wto.org/goods/) accessed 3 October 2017. 